\section{Inheritance of Resistance to the NL-8 Strain of Bean Common Mosaic Necrosis Virus in Bean}

\author{
R. Provvidenti ${ }^{1}$ \\ Cornell University, Department of Plant Pathology, New York State \\ Agricultural Experiment Station, Geneva, NY 14456-0462
}

Additional index words. Phaseolus sp., disease, genetics

\begin{abstract}
Bean common mosaic necrosis virus (BCMNV) includes four African strains, BCMNV-NL3, -NL-5, -NL8, and -TN1, previously considered to be members of the bean common mosaic virus (BCMV) group. Many bean cultivars resistant to BCMNV-NL8 were found to be susceptible to the other strains of the virus. 'California Light Red Kidney' (CLRK) and 'Carbon', resistant to BCMNV-NL8, were crossed with the susceptible cultivars Sanilac or Black Turtle 2 (BT-2). In plants of $F_{1}, F_{2}$, and reciprocal backcross populations involving CLRK $\times$ 'Sanilac' or BT-2 $\times$ 'Carbon', the resistance to BCMVN-NL8 was determined to be conferred by a single dominant factor. The same factor was detected in BCMNV-NL8-resistant 'Great Northern 1140' and 'IVT-7214, when crossed with the susceptible cultivar Stringless Refugee or BT-2.
\end{abstract}

Research conducted on potyviruses considered to be strains of bean common mosaic virus (BCMV) disclosed that a group of four strains differed serologically and in some structural characteristics (McKern et al., 1992; Vetten et al., 1992). Consequently, a new name was proposed for this group, bean necrosis mosaic virus (BNMV) (McKern, et al., 1992) Two years later, the name bean common mosaic necrosis virus (BCMNV) was given by the Plant Virus Subcommittee of the International Committee for Taxonomy of Viruses (ICTV) (1994). This group includes BCMNV-NL3, -NL5, -NL8, and -TN1. The old name was retained for the other known strains, BCMV-CH2, -NL1, -NL2, -NL4, -NL6, -NL7, -PR1, -RU1, -US1, -US2, -US3, -US4, -US5, -US6, -US7, and-US10. Peptide profile data also indicated that the potyviruses, azuki bean mosaic, blackeye cowpea mosaic, peanut stripe, and three soybean isolates (PM, $\mathrm{PN}$, and \#74) are members of the BCMV group (McKern et al., 1992).

Strains of BCMV probably coevolved with Phaseolus species at the American centers of origin, Mesoamerica and the Andes (Kline et al., 1988). These strains can be divided into two subgroups: 1) mosaic inducing strains; and 2) temperature-dependent strains, which at temperatures $\geq 30{ }^{\circ} \mathrm{C}$ may cause systemic necrosis in plants possessing the resistance / gene (Drijfhout et al., 1978). In the United States, the widespread use of certified seeds and the development of resistant cultivars provided, for many years, a very effective control against strains of the BCMV group.

Received for publication 24 Apr. 2000. Accepted for publication 24 Sep. 2000. The cost of publishing this paper was defrayed in part by the payment of page charges. Under postal regulations, this paper therefore must be hereby marked advertisement solely to indicate this fact.

${ }^{1}$ E-mail address: rp13@nysaes.cornell.edu
However, the introduction of bean germplasm infected with strains of BCMNV caused severe epidemics in bean-growing areas of the United States and Canada (Hampton et al., 1983; Kelly, et al., 1984; Provvidenti et al., 1984). These strains of BCMNV originated from African legumes. In common bean (Phaseolus vulgaris L.), they cause foliar symptoms resembling those incited by BCMV, except that in plants possessing only the / gene, strains of BCMNV induce a temperature-insensitive systemic necrosis and premature death (Drijfhout and Bos, 1977; Hubeling, 1972).

In 1982, devastating viral epidemics occurred in bean fields of western New York State, and the causal agent was identified as BCMNV-NL-8 (Provvidenti et al., 1984). This provided the opportunity to compare this strain with BCMNV-NL3,-NL5, and the New York State, BCMV-NY15. The reaction of 60 domestic cultivars growing under controlled conditions (Provvidenti, 1990), indicated that BCMNV-NL8 differed from-NL3, -NL5, and BCMV-NY15. Twenty-three snap bean cultivars were resistant to BCMNVNL-8, but developed systemic necrosis with -NL3 and -NL5 (Table 1). Also, 23 dry bean cultivars were resistant to BCMNV-NL8, but in only a few cases, were resistant or tolerant to -NL3 or -NL5. Nine dry bean cultivars: 'California Light Red Kidney', 'California Dark Red Kidney', 'California White Kidney', 'Canario 107', 'Charlevoix', 'Lasson', 'Manitou', 'Sacramento', and 'Soldier', which were resistant to BCMNV-NL8, were found to be susceptible to BCMNV-NL3, -NL5, and BCMV-NY15. This newly recognized resistance factor was later found in 'Carbon' and a few other bean cultivars (unpublished). Thus, our aim in this investigation was to determine the inheritance of resistance to BCMNV-NL-8 in common beans. most common strain of BCMV occurring in
Cultures of BCMNV-NL3, -NL5, -NL8, and BCMV-NY15 were available from previous studies (Provvidenti, 1990, 1991). The BCMNV strains were maintained in plants of the susceptible 'Black Turtle 2' (BT-2), whereas BCMV-NY15 was propagated in 'California Light Red Kidney' (CLRK). Genetic populations of $F_{1}, F_{2}$, and reciprocal backcrosses were derived from the crosses (CLRK x 'Sanilac') and (BT-2 x 'Carbon'). Of these cultivars, BT-2 is susceptible to all strains of BCMV and BCMNV; CLRK and 'Carbon' are resistant to BCMNV-NL8, but susceptible to the other strains of BCMNV and BCMV; and 'Sanilac' is susceptible to all strains of BCMNV and two strains of BCMV (-NL2 and -NY15) (Drijfhout et al., 1978; Provvidenti, 1990). Inoculum was prepared by triturating young symptomatic BT-2 bean leaves in a $0.05 \mathrm{M}$ phosphate buffer $(\mathrm{pH} 8.5)$ and rubbing extracts on the primary leaves of test plants, after dusting with 400-mesh carborundum. Each test included controls consisting of inoculated and noninoculated plants of resistant and susceptible parents. Inoculated plants that had failed to exhibit any visible systemic symptoms were tested by enzyme-linked immunosorbent assays (ELISAs). Recovery tests were accomplished by inoculating 'Black Turtle 1' (BT-1) beans, which respond to BCMNV-NL8 with local and systemic vascular necrosis, followed by premature death. Serotype A broad-spectrum monoclonal antibody (McAB 3 197-1) was obtained from Dr. Mink (Washington State Univ.), and antiserum to BCMV-US1 (Type strain) had been prepared by Uyemoto et al. (1972). Results were recorded by Microelisa Auto Reader (Spectra II Reader; SLT Labinstruments, Austria). All plants were grown in sterilized clay pots $(550 \mathrm{~mL}$ volume $)$ containing the Cornell artificial mix (sphagnum peat, Whittemore vermiculite, Baker's dolomitic limestone and 10N-5P-10K. Every week, plants were also fertilized with the watersoluble "Start-N-Grow" (20N-20P-20K) (Agway, Syracuse, N.Y.) and treated with Enstar II $\{S$-kinoprene [2-propynyl $(2 E, 4 E)$ (7S)-3,7,11-trimethyl-2-4-dodecadienoate]\} manufactured by Sandoz Afro, Des Plaines, Ill. The insecticide was used for the control of whiteflies and aphids to keep plants free of viral vectors. All the plants were grown in a restricted area of the greenhouse, and natural light was supplemented with fluorescent lights for $16 \mathrm{~h}$ daily, during the winter months. The greenhouse temperature ranged from 26 to $30{ }^{\circ} \mathrm{C}$, relative humidity from $40 \%$ to $60 \%$.

\section{Results and Discussion}

Plants of CLRK and 'Carbon' remained free of systemic symptoms after inoculation with BCMNV-NL8. The ELISA and recovery tests indicated the absence of systemic infection. Both cultivars, however, expressed a local hypersensitive reaction on the inoculated primary leaves. 'Carbon' developed veinal browning, whereas CLRK reacted with 
Table 1. Reaction of snap and dry bean cultivars to one strain of bean common mosaic virus (BCMV-NY15) and three strains of bean common mosaic necrosis virus (BCNMV-NL3, -NL5, and -NL8).

\begin{tabular}{|c|c|c|c|c|}
\hline Cultivar & NY15 & NL3 & NL5 & NL8 \\
\hline \multicolumn{5}{|c|}{ Snap beans } \\
\hline Alliance & $\mathrm{R}^{\mathrm{z}}$ & $\mathrm{N}$ & $\mathrm{N}$ & $\mathrm{N}$ \\
\hline Benton & $\mathrm{R}$ & $\mathrm{N}$ & $\mathrm{N}$ & $\mathrm{R}$ \\
\hline Blazer & $\mathrm{N}$ & $\mathrm{N}$ & $\mathrm{N}$ & $\mathrm{N}$ \\
\hline Bonanza & $\mathrm{R}$ & $\mathrm{N}$ & $\mathrm{N}$ & $\mathrm{R}$ \\
\hline Bounty & $\mathrm{R}$ & $\mathrm{N}$ & $\mathrm{N}$ & $\mathrm{R}$ \\
\hline Burly & $\mathrm{R}$ & $\mathrm{N}$ & $\mathrm{N}$ & $\mathrm{R}$ \\
\hline Bush Blue Lake 47 & $\mathrm{R}$ & $\mathrm{N}$ & $\mathrm{N}$ & $\mathrm{R}$ \\
\hline Bush Blue Lake 92 & $\mathrm{R}$ & $\mathrm{N}$ & $\mathrm{N}$ & $\mathrm{R}$ \\
\hline Bush Blue Lake 94 & $\mathrm{R}$ & $\mathrm{N}$ & $\mathrm{N}$ & $\mathrm{R}$ \\
\hline Bush Blue Lake 109 & $\mathrm{R}$ & $\mathrm{N}$ & $\mathrm{N}$ & $\mathrm{R}$ \\
\hline Bush Blue Lake 247 & $\mathrm{R}$ & $\mathrm{N}$ & $\mathrm{N}$ & $\mathrm{R}$ \\
\hline Checkmate & $\mathrm{R}$ & $\mathrm{N}$ & $\mathrm{N}$ & $\mathrm{R}$ \\
\hline Dandy & $\mathrm{R}$ & $\mathrm{N}$ & $\mathrm{N}$ & $\mathrm{R}$ \\
\hline Eagle & $\mathrm{R}$ & $\mathrm{N}$ & $\mathrm{N}$ & $\mathrm{R}$ \\
\hline Early Galatin & $\mathrm{R}$ & $\mathrm{N}$ & $\mathrm{N}$ & $\mathrm{R}$ \\
\hline Gaelic & $\mathrm{R}$ & $\mathrm{N}$ & $\mathrm{N}$ & $\mathrm{R}$ \\
\hline Gator Green & $\mathrm{R}$ & $\mathrm{N}$ & $\mathrm{N}$ & $\mathrm{R}$ \\
\hline Hi-Style & $\mathrm{R}$ & $\mathrm{N}$ & $\mathrm{N}$ & $\mathrm{R}$ \\
\hline Impr. Tendergreen & $\mathrm{R}$ & $\mathrm{N}$ & $\mathrm{N}$ & $\mathrm{R}$ \\
\hline Labrador & $\mathrm{R}$ & $\mathrm{N}$ & $\mathrm{N}$ & $\mathrm{R}$ \\
\hline Lazer & $\mathrm{R}$ & $\mathrm{N}$ & $\mathrm{N}$ & $\mathrm{R}$ \\
\hline Peak & $\mathrm{R}$ & $\mathrm{N}$ & $\mathrm{N}$ & $\mathrm{R}$ \\
\hline Picker & $\mathrm{R}$ & $\mathrm{N}$ & $\mathrm{N}$ & $\mathrm{R}$ \\
\hline Picor & $\mathrm{R}$ & $\mathrm{N}$ & $\mathrm{N}$ & $\mathrm{N}$ \\
\hline Royal Burgundy & $\mathrm{R}$ & $\mathrm{N}$ & $\mathrm{N}$ & $\mathrm{R}$ \\
\hline Slender Wax & $\mathrm{R}$ & $\mathrm{N}$ & $\mathrm{N}$ & $\mathrm{R}$ \\
\hline True Blue & $\mathrm{R}$ & $\mathrm{N}$ & $\mathrm{N}$ & $\mathrm{R}$ \\
\hline Tenderlake & $\mathrm{R}$ & $\mathrm{N}$ & $\mathrm{N}$ & $\mathrm{R}$ \\
\hline Tenderpod & $\mathrm{S}$ & $\mathrm{S}$ & $\mathrm{S}$ & $\mathrm{S}$ \\
\hline Vitagreen & $\mathrm{R}$ & $\mathrm{N}$ & $\mathrm{R}$ & $\mathrm{R}$ \\
\hline \multicolumn{5}{|c|}{ Dry beans } \\
\hline Black Turtle 1 & $\mathrm{R}$ & $\mathrm{N}$ & $\mathrm{N}$ & $\mathrm{N}$ \\
\hline B. Turtle 2 & $\mathrm{~S}$ & $\mathrm{~S}$ & $\mathrm{~S}$ & $\mathrm{~S}$ \\
\hline B. Turtle Soup T-39 & $\mathrm{R}$ & $\mathrm{N}$ & $\mathrm{N}$ & $\mathrm{N}$ \\
\hline CA Light Red Kidney & $\mathrm{S}$ & $\mathrm{S}$ & $\mathrm{S}$ & $\mathrm{R}$ \\
\hline CA Dark Red Kidney & $\mathrm{S}$ & $\mathrm{S}$ & $\mathrm{S}$ & $\mathrm{R}$ \\
\hline CAWhite Kidney & $\mathrm{S}$ & $\mathrm{S}$ & $\mathrm{S}$ & $\mathrm{R}$ \\
\hline Canario 107 & $\mathrm{~S}$ & $\mathrm{~S}$ & $\mathrm{~N}$ & $\mathrm{R}$ \\
\hline Carmine & $\mathrm{R}$ & $\mathrm{N}$ & $\mathrm{N}$ & $\mathrm{R}$ \\
\hline Charlevoix & $\mathrm{S}$ & $\mathrm{S}$ & $\mathrm{S}$ & $\mathrm{R}$ \\
\hline Clipper & $\mathrm{S}$ & $\mathrm{S}$ & $\mathrm{S}$ & $\mathrm{S}$ \\
\hline Great Northern 31 & $\mathrm{R}$ & $\mathrm{R}$ & $\mathrm{R}$ & $\mathrm{R}$ \\
\hline G. Northern 123 & $\mathrm{R}$ & $\mathrm{T}$ & $\mathrm{T}$ & $\mathrm{R}$ \\
\hline G. Northern 1140 & $\mathrm{R}$ & $\mathrm{T}$ & $\mathrm{T}$ & $\mathrm{R}$ \\
\hline Isabella & $\mathrm{R}$ & $\mathrm{T}$ & $\mathrm{N}$ & $\mathrm{R}$ \\
\hline Kamiakin & $\mathrm{R}$ & $\mathrm{N}$ & $\mathrm{N}$ & $\mathrm{R}$ \\
\hline Kardinal & $\mathrm{R}$ & $\mathrm{N}$ & $\mathrm{N}$ & $\mathrm{R}$ \\
\hline Lark & $\mathrm{R}$ & $\mathrm{T}$ & $\mathrm{N}$ & $\mathrm{R}$ \\
\hline Lasson & $\mathrm{S}$ & $\mathrm{S}$ & $\mathrm{S}$ & $\mathrm{R}$ \\
\hline Linden & $\mathrm{R}$ & $\mathrm{N}$ & $\mathrm{N}$ & $\mathrm{R}$ \\
\hline Manitou & $\mathrm{S}$ & $\mathrm{S}$ & $\mathrm{S}$ & $\mathrm{R}$ \\
\hline Michelite 62 & $\mathrm{~S}$ & $\mathrm{~S}$ & $\mathrm{~S}$ & $\mathrm{~S}$ \\
\hline Midnight & $\mathrm{R}$ & $\mathrm{N}$ & $\mathrm{N}$ & $\mathrm{N}$ \\
\hline Montecalm & $\mathrm{R}$ & $\mathrm{N}$ & $\mathrm{N}$ & $\mathrm{R}$ \\
\hline Redkote & $\mathrm{R}$ & $\mathrm{N} / \mathrm{T}$ & $\mathrm{N}$ & $\mathrm{R}$ \\
\hline Redkloud & $\mathrm{R}$ & $\mathrm{T}$ & $\mathrm{N}$ & $\mathrm{R}$ \\
\hline Royal Red & $\mathrm{R}$ & $\mathrm{N}$ & $\mathrm{N}$ & $\mathrm{R}$ \\
\hline Ruddy & $\mathrm{T}$ & $\mathrm{T}$ & $\mathrm{T}$ & $\mathrm{R}$ \\
\hline Sacramento & $\mathrm{S}$ & $\mathrm{S}$ & $\mathrm{S}$ & $\mathrm{R}$ \\
\hline Sanilac & $\mathrm{S}$ & $\mathrm{S}$ & $\mathrm{S}$ & $\mathrm{S}$ \\
\hline Soldier & $\mathrm{S}$ & $\mathrm{S}$ & $\mathrm{S}$ & $\mathrm{R}$ \\
\hline
\end{tabular}

${ }^{\mathrm{z}} \mathrm{R}=$ resistant, free of systemic infection, mosaic or necrosis; $\mathrm{N}=$ necrotic, systemic vascular necrosis, wilting, and premature death; $\mathrm{T}=$ tolerant, systemic mild mottle or scattered systemic necrotic spots; and S = Susceptible, persistent mosaic and plant stunting. some small spots and limited veinal browning. The susceptible plants of BT-2 and 'Sanilac' responded with green mottle, downward leaf rolling, reduction of leaf size and partial stunting. The $\mathrm{F}_{1}$ plants of both crosses (CLRK x 'Sanilac') and (BT-2 x 'Carbon') reacted to the virus with local infection, but were systematically resistant. The dominance of the resistance factor in $\mathrm{F}_{1}$ plants was confirmed by the reaction of $\mathrm{F}_{2}$ populations, which segregated near the ratio of 3 systematically resistant : 1 susceptible. The progenies of the backcrosses to resistant parents CLRK or 'Carbon' were all systemically resistant, whereas the progenies of the backcross to the susceptible parents, 'Sanilac' or BT-2, segregated in a ratio of 1 systemically resistant : 1 susceptible. Hence, the data in Table 2 indicate that in both CLRK and 'Carbon', the specific resistance to BCMNVNL8 is conferred by a single dominant gene.

For years, the purpose of most of the research on BCMV was the identification of factors for resistance (Ali, 1950; Chamberlain, 1939; Peterson, 1958; Pierce, 1935). The extensive research of Drijfhout (1978), however, provided us with a valuable list of genetic factors that are able to control strains of this virus in beans. He reported that resistance is conferred by: 1$)$ recessive genes $(b c-u, b c-1$, $b c-1^{2}, b c-2, b c-2^{2}$, and $\left.\left.b c-3\right) ; 2\right)$ a dominant hypersensitive gene /; and 3) combinations of these factors. Since all known strains of BCMNV were considered to be members of BCMV, it was logical to assume that resistance to them was conferred by some of the known genes. However, our tests have demonstrated that BCMV-susceptible CLRK and 'Carbon' are resistant to BCMNV-NL8 and the resistance is conferred by a specific, single, dominant factor.

Drijfhout et al. (1978) reported that the bean line 'IVT-7214' was resistant to all known pathotypes of BCMV, including BCMNV-NL8. We also reported that 'Great Northern 1140' (GN-1140) was resistant to some strains of BCMV and BCMNV-NL8 (Provvidenti, 1990). In further work with $\mathrm{F}_{1}$ plants of the crosses ('Stringless Green Refugee' $x$ 'IVT-7214') and $F_{1}$ and $F_{2}$ plants of (GN-1140 $\times$ BT-2), the resistance to BCMNVNL8 was also found to be dominant.

Strains of BCMV and of BCMNV can induce similar foliar symptoms on susceptible bean genotypes, but they can be differentiated by serology, structural properties, and differential hosts. No allelism tests were conducted with the known resistance gene /, consequently, no gene symbol has been assigned to the factor conferring resistance to BCMNV-NL8 in beans. Further studies are also needed regarding the specific resistance factors controlling BCMNV-NL3, -NL5, and -NT1 in P. vulgaris.

\section{Literature Cited}

Ali, M.A. 1950. Genetics of resistance to the common bean mosaic virus (bean virus 1 ) in bean (Phaseolus vulgaris). Phytopathology 40:60979.

Chamberlain, E.E. 1939. Bean mosaic (Phaseolus 1 of Smith, 1937). N.Z. J. Sci. Technol. 20:381A-388A.

Drijfhout, E. 1978. Genetic interaction between Phaseolus vulgaris and bean common mosaic virus with implications for strain identification and breeding for resistance. Agr. Res. Rpt. SBN 902200671 , Wageningen, The Netherlands.

Drijfhout, E. and L. Bos. 1977. The identification of two new strains of bean common mosaic virus. Neth. J. Plant Pathol. 83:13-25.

Drijfhout, E., M.J. Silbernagel, and D.W. Burke. 1978. Differentiation of strains of bean common mosaic virus. Neth. J. Plant Pathol. 84:13-26.

Hampton, R.O., M.J.. Silbernagel, and D.W. Burke. 1983. Bean common mosaic virus strains associated with the bean epidemics in the northwestern United States. Plant Dis. 67:558-661.

Hubbeling, N. 1972. Resistance in beans to strains of bean mosaic virus. Meded Landb. Opzoe. Staat Genet. 28:1025-1033.

International Committee for Taxonomy of Viruses. 1994. Taxonomy and classification of legume-

Table 2. Inheritance of resistance in the common bean (Phaseolus vulgaris L.) to the NL-8 strain of bean common mosaic necrosis virus (BCMNV-NL8).

\begin{tabular}{|c|c|c|c|c|}
\hline \multirow[b]{2}{*}{ Parents and progeny } & \multicolumn{2}{|c|}{ No. plants } & \multirow{2}{*}{$\begin{array}{c}\text { Expected } \\
\text { ratio }(\mathrm{R}: \mathrm{S})\end{array}$} & \multirow{2}{*}{$\begin{array}{r}\text { Goodness } \\
\text { of fit }(P)\end{array}$} \\
\hline & Resistant & Susceptible & & \\
\hline Black Turtle 2 (BT-2) & --- & 77 & & \\
\hline Sanilac & --- & 86 & & \\
\hline CA Light Red Kidney (CLRK) & 78 & --- & & \\
\hline Carbon & 95 & --- & & \\
\hline \multicolumn{5}{|l|}{ CLRK x Sanilac } \\
\hline $\mathrm{F}_{1}$ & 60 & --- & & \\
\hline $\mathrm{F}_{2}$ & 89 & 25 & $3: 1$ & 0.48 \\
\hline $\mathrm{BC}\left(\mathrm{F}_{1} \times\right.$ Sanilac $)$ & 51 & 58 & $1: 1$ & 0.50 \\
\hline $\mathrm{BC}\left(\mathrm{F}_{1} \times \mathrm{CLRK}\right)$ & 65 & --- & & \\
\hline \multicolumn{5}{|l|}{ BT -2 x Carbon } \\
\hline $\mathrm{F}_{1}$ & 106 & --- & & \\
\hline $\mathrm{F}_{2}$ & 92 & 26 & $3: 1$ & 0.47 \\
\hline $\mathrm{BC}\left(\mathrm{F}_{1} \times \mathrm{BT}-2\right)$ & 77 & 80 & $1: 1$ & 0.81 \\
\hline $\mathrm{BC}\left(\mathrm{F}_{1} \times\right.$ Carbon $)$ & 124 & --- & & \\
\hline Great Northern $1140(\mathrm{GN}-1140)$ & 16 & --- & & \\
\hline$(\mathrm{GN} 1140 \times \mathrm{BT}-2) \mathrm{F}_{1}$ & 12 & --- & & \\
\hline$(\mathrm{GN}-1140 \times \mathrm{BT}-2) \mathrm{F}_{2}$ & 54 & 20 & $3: 1$ & 0.65 \\
\hline IVT-7214 & 16 & --- & & \\
\hline Stringless Green Refugee (SGR) & --- & 10 & & \\
\hline$(\mathrm{SGR} \times \mathrm{IVT}-1214) \mathrm{F}_{1}$ & 13 & --- & & \\
\hline
\end{tabular}


infected potyviruses. A proposal from the potyviridae study group of the Plant Virus Committee of ICTV Arch. of Virol. 139:231-235.

Kelly, J.D., A.W. Saettler, and M. Morales. 1984. Necrotic strain of bean common mosaic virus in Michigan. Bean Improv. Coop. Annu. Rpt. 27:3839.

Kline, R.E., S.D. Wyatt, and W.J. Kaiser. 1988. Incidence of bean common mosaic virus in USDA Phaseolus germplasm collection. Plant. Dis. 73:301-302.

McKern, N.M., G.I. Ming, O.W. Barnett, A. Mishra, L.A. Whittaker, M.J. Silberhagel, C.W. Ward, and D.D. Shukla. 1992. Isolates of bean com- mon mosaic virus comprising two distinct potyviruses. Phytopathology 82:923-929.

Peterson, H.J. 1958. Beitrage zur genetik vor Phaseolus vulgaris L. auf infektion mit Phaseolus Virus 1 stammn Voldagsen. Zeitschrift Planz 39:187-224.

Pierce, W.H.. 1935. The identification of certain viruses affecting leguminous plants. J. Agr. Res. 51:1017-1039.

Provvidenti, R. 1990. Reaction of some leading cultivars of African and indigenous strains of bean common mosaic virus. Bean Improv. Coop. Annu. Rpt. 33:167-168.

Provvidenti, R. 1991. Inheritance of resistance to the NL-8 strain of bean common mosaic virus in Pisum sativum. J. Hered. 83:353-355.

Provvidenti, R., M.J. Silbernagel, and W.Y. Wang. 1984. Local epidemics of NL-8 strain of bean common mosaic virus in bean fields of western New York. Plant Dis. 68:1092-1094.

Uyemoto, J.K., R. Provvidenti, and W.T. Schroeder. 1972. Serological relationship and detection of bean common mosaic virus in agar gel. Ann. Appl. Biol. 71:235-242.

Vetten, H.J., D.E. Lesemann, and E. Maiss. 1992. Serotype A and B of bean common mosaic virus are two distinct potyviruses. Arch Virol. (Suppl. 5):415-431. 